\title{
MATRIX OF VULNERABILITY OF DECENTRALIZED AREAS TO LOCAL ENERGY SECURITY RISKS IN THE NORTHERN AND ARCTIC ZONES IN THE STRUCTURAL SET OF SOLUTIONS
}

\author{
Violetta Kiushkina ${ }^{1}$, Boris Lukutin ${ }^{2}$ \\ ${ }^{1}$ Chukotsk branch of the North-Eastern Federal University Scientific, Anadyr, Russia \\ ${ }^{1}$ Technical Institute (branch) of North-Eastern Federal University Scientific named after M.K. Ammosov, Neryungri, Russia \\ ${ }^{2}$ National Research Tomsk Polytechnic University Energy Engineering School, Tomsk, Russia
}

\begin{abstract}
The tension of the state of decentralized power supply systems in the northern regions, including the Arctic zones, has always been determined by the specific features of their geographical location and the functioning of the economy, which in themselves generate a number of local energy security risks. Nevertheless, both modern and retrospective analysis of energy zones in isolated hard-to-reach territories retains an assessment of the crisis of the situation without the dynamic type of its improvement in ensuring energy security. The aggregate analysis of the formed risk matrix with the heterogeneous nature of their sources, the categorization of the depth of consequences and the probability of implementation, made it possible to obtain a map of local risks of energy security in decentralized regions. On the basis of this, an approach and structure of a set of recommendations for improving energy security is presented in the model of combining the rank of the indicator's importance, the priority of risks and the expected social, environmental and economic effects in a reasonable option for choosing solutions and recommended measures to ensure a stable state and development of decentralized zones of power supply and energy facilities of territories Northern regions and Arctic zones.
\end{abstract}

\section{Introduction}

The combination of territorial factors (specific features of the geographical location of the decentralized zones of the northern regions) and situational factors of autonomous energy forms the structural basis for the model of the local hazard measure - the risks of reducing the acceptable level of energy security (EnS) of the studied territories.

Accept that the "oppressed" state of the decentralized energy zone in relation to energy security - a decrease in indicators and abilities that characterize the provision of comfortable living conditions for the population and the functioning of energy facilities, with a certain degree of vulnerability of the EnS level protection associated with negative events (risk intensity, duration of exposure to risks, severity consequences, dynamics of changes in risks and threats).

Based on the analysis of factors, conditions and statistical data for hard-to-reach territories of the regions of the North and the Arctic zones with the features of decentralized power supply and the composition of their inherent threats, a list of examples of local risks was formed (table 1) [1]. The analysis of groups of factors showed that the state of energy security of decentralized power supply complexes is influenced by many factors, among which the most significant are shown in Figure 1. These factors are interconnected with other factors of a different nature that enhance or mitigate the impact of a certain threat, and at the same time, they themselves affect stabilizing others.

Fig 1. Influencing factors on the state of EnS of decentralized energy complexes

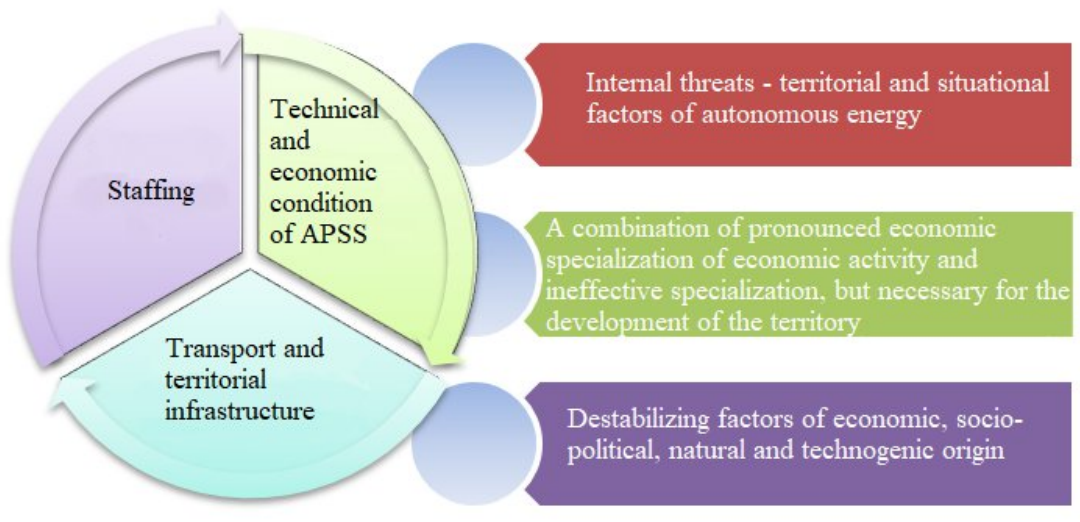




\section{Local risks of energy security of decentralized areas}

Table 1. Possible local risks of EnS of the decentralized power supply zone

\begin{tabular}{|c|c|c|}
\hline № & Risk name & Threat status, probability of transformation \\
\hline$R_{1}$ & $\begin{array}{l}\text { The risk of undersupply of electrical energy due } \\
\text { to a disruption in the supply (natural conditions, } \\
\text { financial instability) or the supply of incomplete } \\
\text { fuel resources (aggravated by the dominance of } \\
\text { one fuel resource) }\end{array}$ & $\begin{array}{l}\text { Strategic character, weakening with diversification of } \\
\text { resources, formation of logistics of guaranteed and } \\
\text { reliable fuel supplies, taking into account the climatic } \\
\text { characteristics of the northern regions, transportation } \\
\text { routes, pricing policy }\end{array}$ \\
\hline$R_{2}$ & $\begin{array}{l}\text { The risk of periods of forced downtime and } \\
\text { emergency situations due to low / lack of } \\
\text { qualifications of personnel }\end{array}$ & $\begin{array}{l}\text { Current character, zeroed when the educational cluster } \\
\text { is strengthened }\end{array}$ \\
\hline$R_{3}$ & $\begin{array}{l}\text { The risk of a decrease in the rate of optimization } \\
\text { of the structure of autonomous power supply } \\
\text { systems (APSS) in case of insufficient / lack of } \\
\text { investment }\end{array}$ & \multirow[t]{4}{*}{$\begin{array}{l}\text { Strategic character, weakening with the strengthening } \\
\text { of trends in the introduction of new available } \\
\text { technologies, the fulfillment of established } \\
\text { requirements, an orientation towards social investment }\end{array}$} \\
\hline$R_{4}$ & $\begin{array}{l}\text { Risk of disruption of uninterrupted power supply } \\
\text { to consumers }\end{array}$ & \\
\hline$R_{5}$ & $\begin{array}{l}\text { The risk of high losses (energy, consumption of } \\
\text { fuel resources) due to an ineffective process of } \\
\text { electricity production and reduced technical and } \\
\text { economic indicators of the APSS }\end{array}$ & \\
\hline$R_{6}$ & $\begin{array}{l}\text { The risk of long-term elimination of a failure due } \\
\text { to an unacceptable reaction to an accident } \\
\text { (climatic conditions, personnel situation, } \\
\text { transport-territorial factors) }\end{array}$ & \\
\hline$R_{7}$ & $\begin{array}{l}\text { The risk of undersupply of electrical energy due } \\
\text { to the lack of strategic supply of fuel in the } \\
\text { required volume of decentralized energy } \\
\text { complexes (DECPS) }\end{array}$ & $\begin{array}{l}\text { Strategic character, weakened by resource } \\
\text { diversification and targeted regional policy action }\end{array}$ \\
\hline$R_{8}$ & $\begin{array}{l}\text { Risk of high equipment failure rate due to } \\
\text { degradation state }\end{array}$ & $\begin{array}{l}\text { Strategic character, weakening with the strengthening } \\
\text { of trends in the introduction of new available } \\
\text { technologies, the fulfillment of established } \\
\text { requirements, an orientation towards social investment }\end{array}$ \\
\hline$R_{9}$ & $\begin{array}{l}\text { The risk of long-term restoration of equipment } \\
\text { due to the complexity of the service (lack of spare } \\
\text { parts for a wide range of types of units, limited } \\
\text { competence of working personnel) }\end{array}$ & $\begin{array}{l}\text { Current character, zeroing in case of complex } \\
\text { implementation of organizational and managerial } \\
\text { development measures }\end{array}$ \\
\hline$R_{10}$ & $\begin{array}{l}\text { The risk of increasing the cost of electricity } \\
\text { production }\end{array}$ & \multirow[t]{2}{*}{$\begin{array}{l}\text { Strategic character, weakening with resource } \\
\text { diversification }\end{array}$} \\
\hline$R_{11}$ & $\begin{array}{l}\text { The risk of an increase in the number of insolvent } \\
\text { population - an increase in restrictions on } \\
\text { expenditure items }\end{array}$ & \\
\hline$R_{12}$ & $\begin{array}{l}\text { The risk of inappropriate priority of the use of } \\
\text { funds }\end{array}$ & $\begin{array}{l}\text { Current character, weakening when adjusting regional } \\
\text { policy, the formation of internal sources of } \\
\text { development of the territory }\end{array}$ \\
\hline$R_{13}$ & $\begin{array}{l}\text { The risk of an unacceptable decrease in the } \\
\text { energy efficiency of DECPS }\end{array}$ & \multirow[t]{2}{*}{$\begin{array}{l}\text { Current nature, weakening with strengthening trends in } \\
\text { the introduction of new available technologies }\end{array}$} \\
\hline$R_{14}$ & $\begin{array}{l}\text { The risk of unacceptable losses of electricity due } \\
\text { to inefficient transmission }\end{array}$ & \\
\hline
\end{tabular}

The list should vary based on the individually analyzed territories where the decentralized energy complex of power supply operates, and the clearly established composition of the EnS threats for the current period of time. It is advisable to single out a group of risks for EnS associated with an internal threat specific to decentralized energy zones.
The risk of undersupply of electrical energy associated with fuel supply for such energy zones characterizes the failure to meet the requirements for fuel and energy saving to consumers, based on the definition of EnS, which can bring a natural threat (sharp and longterm adverse natural phenomena, climatic changes in the overlap of the navigation terms sea-river-winter road), financial and economic threat (insolvency of the 
population, spending of funds in case of unplanned deposit and additional equipment to release delivery routes, ineffective use of energy resources with inefficient DECPS, one-sidedness of energy saving measures, insufficient reliability of the tank farm of fuel resources, absence and limitation of permanent transport links in during the year between the zones, lack of diversification of power supply, insufficient fuel reserves), which led to interruptions and untimely supplies of fuel resources and a shortage of electric energy in winter time.

The risk of downtime of DECPS and unacceptable decrease in the efficiency of DECPS associated with staffing characterizes the violation of the reliability component of EnS, which can bring a pronounced social, personnel, and labor resource threat (low qualification of personnel, lack of qualified personnel, low qualifications of engineering and technical workers, weak social responsibility), which led to an increase in equipment failures, erroneous decisions, power outages.

For decentralized energy zones, in contrast to other territorial entities and centralized systems, due to the specifics of the existence and autonomy of power supply, there are no risks that are insignificant for the state of EnS. This is due to the high degree of susceptibility to the impact of real and potential threats, primarily generated by the properties of territories, as the internal potential of a source of risk. Acceptable (permissible) risk (ALARA principle - "as low as possible within reasonable") combines technical, social and economic aspects that require joint consideration. For decentralized zones, the ALARA principle is implemented to the level of conditional probability for the current period of time.

\section{Matrix of vulnerability of decentralized energy zones}

The elements of risk are the probability and sources of origin of the risk, which is described as a combination with the element of the potential consequences of its exposure. In the absence of relevant statistical information, the task of constructing a risk matrix simplifies the use of a point assessment of the probability of risk occurrence and the severity of consequences. In accordance with this, for the studied territories, a classification of the point assessment of the probability of occurrence (table 2) and the severity of the consequences of risks (table 3) for EnS was formed, using the main provisions of the theory of risks [2], deeply studied and adapted in works and developments to assess individual regions [3].

The risk probability classes are determined using a gradation of points with a large step and descriptions, taking into account the specifics for autonomous power supply systems, which recognizes only the rigid boundaries of their state in the current conditions.

Risk analysis uses the levels of consequences characteristic of decentralization conditions and the descriptions associated with them. The class of the category of consequences according to the degree of "destruction" and the attainability of the level of susceptibility and vulnerability of EnS for a specific territory in conditions of autonomy, isolation, and severity of the climate.

Table 2. Classification of the probability of risks

\begin{tabular}{|c|l|l|l|}
\hline$P_{j}$ & \multicolumn{1}{|c|}{$\begin{array}{c}\text { Weight } \\
\text { coefficient }\end{array}$} & Description & $\begin{array}{l}\text { Justification of } \\
\text { risk } \\
\text { manifestation }\end{array}$ \\
\hline$P_{1}\left(R_{i,}, 5\right.$ points & $\begin{array}{l}\text { Absolutely } \\
\text { accurate } \\
\text { with high } \\
\text { probability }\end{array}$ & $\begin{array}{l}\text { Expressed } \\
\text { territorial- } \\
\text { geographical, } \\
\text { natural, } \\
\text { technological, } \\
\text { socio-economic } \\
\text { factors }\end{array}$ \\
\hline$P_{2}\left(R_{i,} 3\right.$ points & $\begin{array}{l}\text { Really with } \\
\text { the } \\
\text { expectation } \\
\text { of a random } \\
\text { negative } \\
\text { event }\end{array}$ & $\begin{array}{l}\text { Expressed } \\
\text { territorial- } \\
\text { geographical, } \\
\text { natural } \\
\text { situational and } \\
\text { factors } \\
\text { autonomy }\end{array}$ \\
\hline$P_{3}\left(R_{i}, 1\right.$ points & $\begin{array}{l}\text { Unlikely, but } \\
\text { acceptable } \\
\text { under } \\
\text { existing } \\
\text { conditions }\end{array}$ & $\begin{array}{l}\text { Expressed } \\
\text { territorial- } \\
\text { geographical, } \\
\text { natural factors }\end{array}$ \\
\hline
\end{tabular}

Table 3. Classification of the severity of the consequences of risks

\begin{tabular}{|c|c|c|c|}
\hline \multicolumn{2}{|c|}{$\begin{array}{c}\text { Class } \\
\text { weight } \\
\text { coefficient }\end{array}$} & $\begin{array}{l}\text { Consequences } \\
\text { to the level of } \\
\text { "oppression" }\end{array}$ & $\begin{array}{l}\text { Compliance with the } \\
\text { level of risk }\end{array}$ \\
\hline$\Pi_{1}$ & $\begin{array}{l}5 \\
\text { points }\end{array}$ & $\begin{array}{l}\text { High / } \\
\text { emergency } \\
\text { state }\end{array}$ & $\begin{array}{l}\text { Unacceptable with } \\
\text { the transition to an } \\
\text { emergency state, } \\
\text { leading to a serious } \\
\text { threat to EnS / its } \\
\text { components or a } \\
\text { complete disruption } \\
\text { of activities (requires } \\
\text { a decrease in the } \\
\text { degree of impact for } \\
\text { the further existence } \\
\text { and functioning of } \\
\text { the decentralized } \\
\text { zone }\end{array}$ \\
\hline$\Pi_{2}$ & $\begin{array}{l}3 \\
\text { points }\end{array}$ & $\begin{array}{l}\text { Borderline / } \\
\text { depressive state }\end{array}$ & $\begin{array}{l}\text { Unacceptable in } \\
\text { conditions of } \\
\text { autonomy, with the } \\
\text { loss of some } \\
\text { functions, caused by } \\
\text { significant changes } \\
\text { (requires an } \\
\text { assessment } \\
\text { measures to reduce } \\
\text { the degree of impact) }\end{array}$ \\
\hline$\Pi_{3}$ & $\begin{array}{l}1 \\
\text { points }\end{array}$ & $\begin{array}{l}\text { Weak / } \\
\text { conditionally } \\
\text { safe current }\end{array}$ & $\begin{array}{l}\text { Acceptable } \\
\text { tolerable without } \\
\text { consequences, as a }\end{array}$ \\
\hline
\end{tabular}




\begin{tabular}{|l|l|l|}
\hline & state & $\begin{array}{l}\text { prerequisite for the } \\
\text { possibility of } \\
\text { manifestation } \\
\text { (requires continuous } \\
\text { monitoring of the } \\
\text { situation and in the } \\
\text { absence and with } \\
\text { weak symptoms of } \\
\text { the appearance of } \\
\text { danger) }\end{array}$ \\
\hline
\end{tabular}

\begin{tabular}{|c|c|c|c|c|}
\hline & $\Pi_{3}$ & $\Pi_{2}$ & $\Pi_{l}$ & \\
\hline & 5 & 15 & 25 & $R_{1}$ \\
\hline & 3 & 9 & 9 & $R_{2}$ \\
\hline & 3 & 9 & 9 & $R_{3}$ \\
\hline & 3 & 9 & 9 & $R_{4}$ \\
\hline & 3 & 15 & 15 & $R_{5}$ \\
\hline \multirow[t]{6}{*}{ RISK RATIO = } & 5 & 25 & 25 & $R_{6}$ \\
\hline & 3 & 9 & 9 & $R_{\gamma}$ \\
\hline & 5 & 25 & 25 & $R_{\varepsilon}$ \\
\hline & 9 & 9 & 1 & $R_{c}$ \\
\hline & 5 & 25 & 5 & $R_{1}$ \\
\hline & 15 & 3 & 3 & $R_{2}$ \\
\hline
\end{tabular}

Pre-decentralized territories, on the example of the Republic of Sakha (Yakutia), as a leader in terms of the scale of operation of small-scale energy facilities in conditions of discomfort, were subjected to clustering according to the manifestation of the intensity of factors prerequisites for risks (territorial-geographical, situational for autonomy). For the example under consideration, an analysis of the local risks of the EnS was carried out and a matrix of vulnerability of the decentralized territories of the North and the Arctic zones to them was compiled. As a result of the aggregate analysis of the general matrix of local risks (1), and the categorization of the depth of damage and the probability of risk realization (2), a map of EnS local risks (3) was obtained for the whole decentralized energy supply zone

of the study area, excluding risks with index 10-12 this research view.

Thirty five experts took part in the procedure for judging the formation of a vulnerability matrix and a vector of threats for decentralized energy zones, twenty five of whom belong to a group of scientists (professors, associate professors), ten - to specialists, managers of production facilities (chief engineers, chief power engineers, chiefs of power supply regions, chief engineers electrical networks of the East, etc.). The involvement of a wide range of specialists as experts, most of whom are related to the autonomous power industry of the Far East, which is the leader in the scale of operation of small-scale energy facilities and territorial affiliation to the decentralized sector, allows us to assume a priori a sufficiently high reliability and representativeness of the initial expert assessments. The conclusions of the expert practitioners are based on their own professional experience in decentralized power supply systems. The risk analysis also includes the results of many years of research into the features of decentralized power supply in the North: retrospective collection of data on situations; statistical data of periodic observation of the relevant industry services at the facilities of decentralized power supply systems in the North and the Arctic.

Group A indicates the dominant dependence on the factors of autonomy and potential of territories to generate risks in the conditions of existence. Group B the predominance of dependence on sources associated with economic factors in conjunction with the specialization of economic activities. Group $\mathrm{C}$ represents the key impact of a group of threats with the essence of an ineffective level, incomplete focus, imperfection and low dynamism in the formation and implementation of the economic policy of the region, regional energy security policy.

The local risk map is a visual diagram of the interpretation of the most vulnerable point in the EnS through the characteristic of a certain risk that may appear for a cluster of decentralized territories with the most unfavorable consequences. The highest risk priority (criticality coefficient) in the map reflects the most potentially dangerous risk, taking into account the damaging factors for the territory in comparison with others, represents the rank of risks, which will allow taking measures in advance to prevent and neutralize them. The cells of the map, in which the "Risk ratio" has the maximum index, show the realization of the threat with the most severe consequences for the decentralized zone in the conditions of its existence. Namely, for a separate example of decentralized territories [4], in case of manifestations of factors of failure in the supply of fuel resources caused by climatic and other situations, and manifestations of technical and technological factors of energy complexes, aggravated by isolation, limited availability, low competence and the level of operating personnel. What entails a probable shortage of electricity and heat energy to the consumer with the possible manifestation of severe consequences during long periods of a sharp cold snap. A more individual consideration of the degree of vulnerability of each 
decentralized zone shows the likelihood of the manifestation of a set of sources and situations that give rise to the realization of risks of a certain group, which will reveal either the duration of the aggravation of the consequences, or its short duration with rapidly eliminating violations and failures.

Also, when carrying out the analysis, the sphere of vital activity of each municipal formation of the investigated decentralized energy zones was taken into account. As a result, three spheres of varying degrees of severity of economic specialization of economic activity were formed: agricultural, industrial spheres, and a mixed group of regions in which agriculture and industry are developed approximately equally. The conducted clustering within each group made it possible to identify the most vulnerable spots. This analysis for the period under review is a good basis for developing top-priority recommendations for neutralizing threats to energy security in groups of the same type.

\section{Structured diagram of the focus of measures to improve the energy security of decentralized energy zones}

The performed analysis is incorporated into a generalized model (figure 2) of the combination of the rank of the importance of the indicator, the manifested group of aggravating factors of specificity, the priority of the risks of the map of local risks of the developed list, the expected effects of the direction of the proposed measures for decentralized power supply zones and the choice of solutions for the energy sector of the territories of the Northern regions and the Arctic zones.

The structured scheme allows you to form an individual trajectory of each territory in successful positions for increasing the EnB, using a matrix and a map of local risks to plan a reasonable focus of activities as a composite tool for analyzing and managing the energy security of decentralized energy zones of such complex territories.

The structural model is subject to systematic revision due to a possible change in reality and a change in the form of actions (strengthening / weakening) of various factors for threats. This makes it possible to form measures of a permanent nature, to define a tough area of monitoring, to reduce the risks of forming incorrect decisions in energy policy and the choice of the sequence of investment and other measures.

As a whole, the tool for analyzing and managing energy security through assessing the impact of local risks of the EnS and understanding changes in its index should create conditions for building a competent, appropriate and effective regional energy security policy. Drawing up individual maps of the situation of decentralized power supply as part of regional energy security should include the context of adequacy and usefulness for conceptualizing threats and challenges, forming an advanced policy for the stable implementation of preventive measures to neutralize risks in a complex relationship with the dynamics of changing factors, conditions, situations, objectives and goals of sustainable, strategic and socio-economic development. Energy security risk management of territories and electrification facilities in a decentralized environment limited by various factors and conditions should be a fixed level in the regional segment of the state assessment.

As a consequence of the impact of local risks of EnS for a decentralized area, there is a potential combination of a decrease in energy supply levels and a comprehensive provision of comfortable living conditions for the population, the disappearance of the culture of the indigenous peoples of the North (IPN), a violation of the eco-heritage of the North and fishing zones, a disturbance of the environment for the traditional form of nature management (reindeer husbandry and etc.). in general, the "damage" to the social component of the EnS is characterized as the essence of the EnS of a decentralized zone, which can bring a socio-political threat (unaddressed actions of regional authorities, which led to an energy imbalance of the territory, stagnation of economic efficiency, deterioration of the availability of electricity to the consumer), management and legal threat (ineffectiveness of regional and social policy, which led to the same consequences).

The observed stagnation of the socio-economic development of the decentralized zone, the growth of differentiation of the level and quality of life of the population of the decentralized zone, persist due to the conditions in which the DECPS functions and are of a strategic nature of an immediate decision. Adjustment of regional policy - development by identifying the merits and advantages of each decentralized zone, strengthening the effective focus of measures for the development of the territory in the changes in the energy structure of modern energy.

Thus, the analysis has identified the most critical set of identified vulnerabilities in the decentralized regions of the North and the Arctic zones. The proposed vulnerability matrix makes it possible to assess and predict the impact of local risks associated with individual threats, reflecting to a greater extent the specificity of the territories in combination with the autonomy of power supply and creating the greatest possibility of causing damage to decentralized energy. The resulting map of local risks of decentralized areas, taking into account these factors, gives an idea of the risks with a high criticality coefficient, and the need for constant monitoring of changes in their dynamics, measuring significant indicators and the general level of energy security of the area. The proposed structure for the choice of measures allows plan targeted criteria for choosing the direction of measures, to correctly assess their rationality and appropriate sequence for the energy zone or their groups with the same type of impact of threats. 


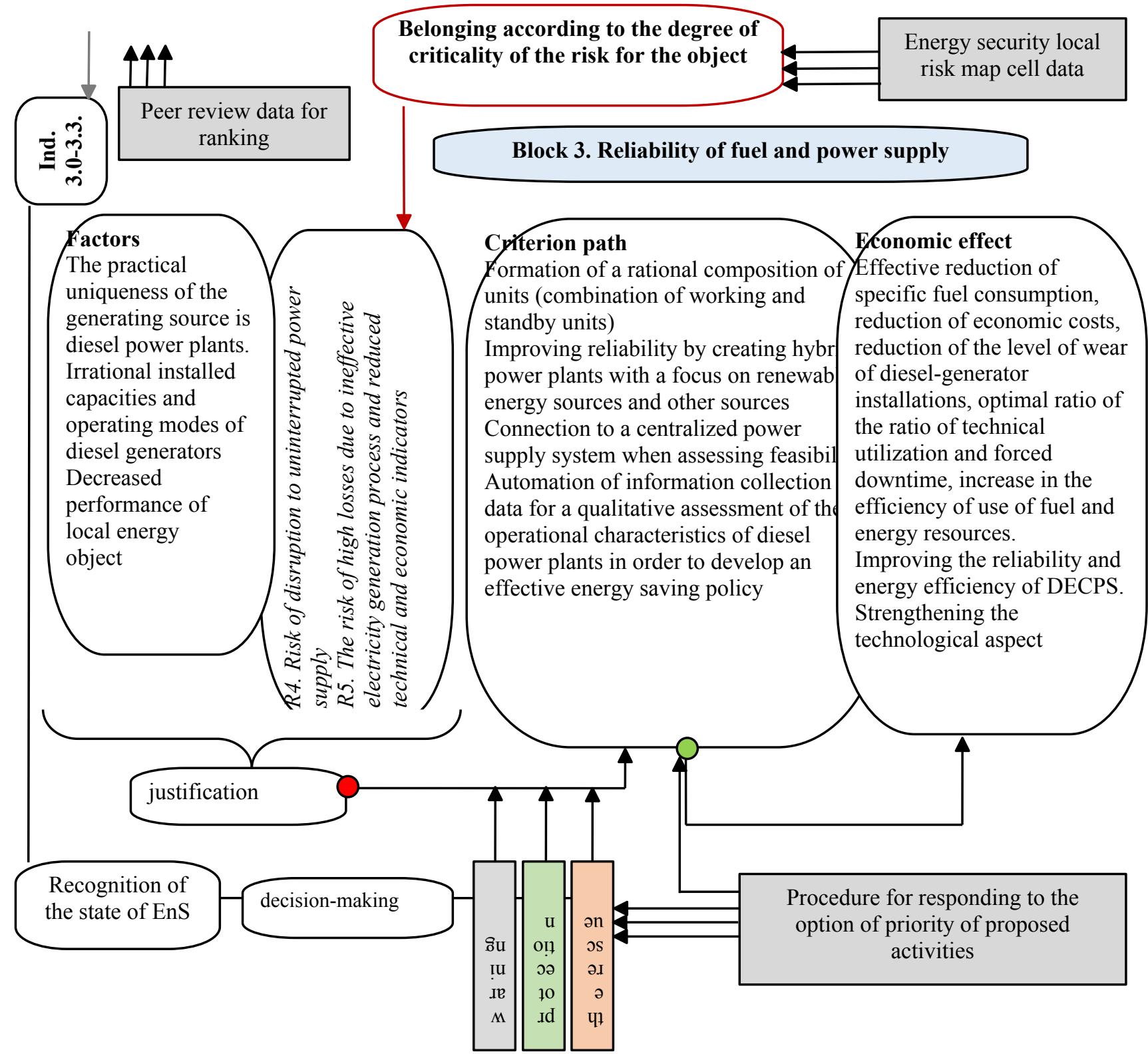

Fig. 2. A fragment of the structural diagram of the substantiation of the choice of the direction of measures to maintain the conditions for the implementation of the ENB of the infrastructural isolated DECPS territories of the North and the Arctic zone of the Russian Federation

Reference

1. V. Kiushkina. Risks of reduced local energy security of isolated territories of the Northern regions and the Arctic zones. Regional energy and energy saving. 1, 48 (2019)

2. Yachia L., Nikonov V. Risk Management (based on the results of the work of the Working Group of the European Economic Commission of the United Nations). 1, 4-22 (2014)

3. Saveliev V.A., Bataeva V.V. Assessment of the risk of reducing the energy security of the region. Bulletin of the Ivanovo State Power Engineering University. 3 (2013)
4. Kiushkina V. R., Reev S.N. Regional assessment indicators and energy security risks of decentralized energy zones in the Arctic. Collection of materials of the V International Arctic Conference 2020. 32-33 (2020) 